\title{
非常に短い臨界ノズルとスロート近傍にステップを持つ 臨界ノズルの流量特性と流速分布
}

\author{
石 橋 雅 裕* \\ Critical Flowrate Characteristics and Flow Velocity Distributions \\ of Very Short and Step Critical Nozzles
}

Masahiro IsHIBASH ${ }^{*}$

\begin{abstract}
Critical flowrate characteristics of very short and step nozzles were investigated experimentally. All the nozzles have identical geometry for their inlet contractions complying with ISO 9300, however, they were cut or have a step exactly at or slightly after the throat. Calibration of these nozzles at various pressure ratios against another critical nozzle connected in series revealed considerable differences in their critical flowrate characteristics. For example, quadrant nozzle that was cut exactly at its throat has a larger flowrate by $0.2 \%$ than that of toroidal throat Venturi nozzles when the pressure ratio is low, however, it decreases when the pressure ratio is increased and finally takes the same value as that of the Venturi nozzles at the pressure ratio of 0.5 . Step nozzle, which has a very small step at its throat, has the same flowrate as the quadrant nozzle at low pressure ratio but keeps the same value all the way in the critical condition regardless of the pressure ratio. Flow velocity distributions estimated from recovery temperature distributions measured by a thin thermocouple wire traversed in the flow through these critical nozzles explain each flowrate characteristics very well as well as reveal lots of information on their flow structures, which can not be obtained by the traditional measurements.
\end{abstract}

Key Words : discharge coefficient, quadrant nozzle, Venturi nozzle, recovery temperature, flow velocity distribution

\section{1.はじめに}

臨界ノズルは，気体流量の標準体系において，標準設備と つぎの階層をつなぐトランスファーとして古くから重要な役 割を果たしている1) 3). また, 近年では, 安定した流量が瞬 時に達成されることに着目し，さまざまな階層での使用も増 えてきた ${ }^{4), 5)}$. この普及に伴い, 臨界ノズルの使用範囲が小 流量域側に広くなり, 低レイノルズ数における非臨界現象, すなわち，理論的にはディフューザ効果によって臨界するは ずの圧力比で流量が $0.1 \%$ オーダーで減少する現象が大きく 取り上げられるようになってきた。この現象解明のため, 各 国で精力的に研究が行なわれているが6),7), その発生機構は 未だ全く解明されていない.たとえば，最新の国際規格案8) では, 低レイノルズ数に扔ける使用では圧力比を 0.5 よりも 十分に下げることが推奨されている。また，スロート直後に

\footnotetext{
* 産業総合技術研究所 流量標準研究室

つくば市梅園 1-1-1 中央第 3 事業所

* Flow Standards Section National Institute of Advanced Industrial Science and Technology, 1-1 Umezono 1, Tsukuba-city

(Received April 23, 2003)

(Revised December 29, 2003)
}

ステップを設け，そこにあけられた静圧孔を通してスロート における静圧を直接測定し，臨界を確認する方法も提案され ている ${ }^{9}$.

一方，筆者は，超精密加工ノズルを用いた研究10 12) の一 環として，加工長を短くして加工を容易にするという観点か ら，スロートまたはスロート直後で切断したステップノズル を製作し，その特性を定積槽システムで測定したことがあ る13).これによると, スロート直後の $0.1 \mathrm{D}(\mathrm{D}$ はスロート 直径)の範囲の壁面の有無は, 流量に $0.1 \%$ オーダーの差を もたらす。この特性差の原因として，エッジから発生した膨 張波による流れの加速等が考えられたが，当時にはその実証 方法が無かったため，あくまでも推測の域を出ず，また，そ の詳細は全く不明のままであった。

近年，筆者は，遷音速流れ場に細線熱電対線を挿入して回 復温度分布を測定し，これに基づいて流速分布を推定する方 法を提案した ${ }^{14)}$. 熱電対線では感度が接点に集中しているた め, 線の長さにかかわらず測定位置が厳密に決まり，また， その測定体積が線径と同じオーダーとなる。そのため, 線径 が $10 \mu \mathrm{m}$ オーダーの長い熱電対線を用い, 測定位置から十 分離れた位置でサポートすることにより, サポートおよび線 の挿入による乱れの影響を抑えながらも $10 \mu \mathrm{m}$ オーダーの 
空間分解能が達成できる。この点において，一般に普及して いる熱線流速計とは全く異なる結果をもたらす。これによ り, 流路直径 $10 \mathrm{~mm}$ 程度の不透明で軸対象な臨界ノズル内 の流速分布の詳細を明らかにすることができる．本論文で は，この方法を用いて各種ステップノズルの流速分布を測定 し，その結果がそれらの流量特性の差を明解に説明すること を報告する。

本論文では，はじめに，各種ステップノズルの臨界流量の 圧力比依存性をノズルの直列接続法により測定した結果につ いて述べる，つぎに，細線熱電対線を用いて各ノズルの回復 温度分布を測定した結果を示し，これらがそれぞれの流量特 性の特徴を明解に説明することを示す。

\section{2. 測定対象ノズルおよびその流量特性}

測定対象としたノズルは，超精密加工旋盤で製作された HPN (High-precision nozzle) である。その流路の形状誤差 はほぼ士1 $\mu \mathrm{m}$ 以下であり，同一形状として製作された HPN は個体差を持たず，国家標準のばらつきの範囲内で同 じ流出係数を持う ${ }^{13)}$.

測定対象としたノズルの形状は，Fig. 1 の上側の左 2 種， すなわち，正確にスロート位置で切り取られた Q夕イプ(四 分円ノズル)，および，入り口側の円環絞りがそのままの曲 率でスロート後方 $3^{\circ}$ にまで回り込む $\mathrm{S}$ タイプ(スロート直径 を $\mathrm{D}$ とすると，長さ $0.1 \mathrm{D}$ の非常に短いディフューザを持 つトロイダルスロートベンチュリノズル)である。これらの スロート直径および体積流量は，それぞれ $13.4 \mathrm{~mm}$ および $100 \mathrm{~m}^{3} / \mathrm{h}$ である。

これらのほかに，一般的長さのディフューザを持つ一体型

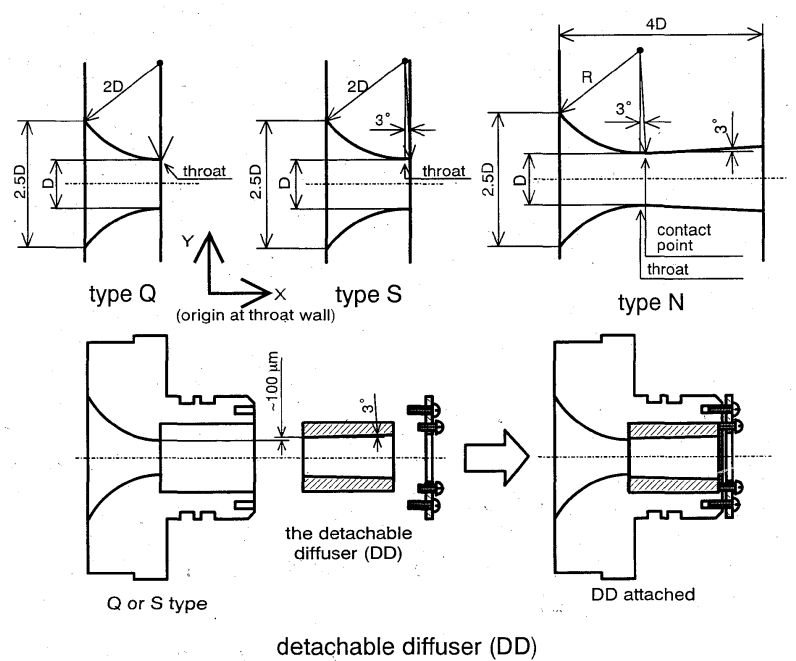

Fig. 1 Designs of the nozzles to be measured. Type $\mathrm{N}$ is a common toroidal throat Venturi nozzle complying with ISO 9300. Type $\mathrm{Q}$ is a quadrant nozzle, which has exactly no diffuser. Type $\mathrm{S}$ is a toroidal throat Venturi nozzle with a very short diffuser of $0.1 \mathrm{D}$ length. $\mathrm{D}=$ $13.4 \mathrm{~mm}$ in all the nozzles. When the detachable diffuser is attached to the type Q or S nozzle, there is a step existing at the contact plane, height of which is less than $0.1 \mathrm{~mm}$.
ノズルである N タイプ (ISO 9300 に規定されるトロイダル スロートベンチュリノズルに準拠）を，基準の特性を持つも のとして用いた。このスロート直径は，同じく $13.4 \mathrm{~mm} て ゙$ ある.

$\mathrm{Q}$ および S タイプのノズルは，Fig. 1の下に示す後付ディ フューザ DD を後方から挿入することにより，その臨界背圧 比を改善することができる。このときの流路形状は，N夕 イプとほとんど同じであるが，後付ディフューザの入り口半 径がノズルの出口半径よりも若干大きいため，スロートまた はその $0.1 \mathrm{D}$ 後方にステップを持つことになる。このステッ プの大きさは，0.01D(約 $0.1 \mathrm{~mm}$ ) 以下である.

臨界ノズルの流量特性は流出係数で表わすことができる. 一般的な使用状況下では，ノズルの上流側圧力がほぼ一定で あれば，流出係数の変化がそのまま流量の変化を表わす。 流出係数 $C_{d}$ は, 次式で定義される.

$$
\begin{aligned}
& C_{d}=\frac{Q_{\text {actual }}}{Q_{\text {theo }}} \\
& Q_{\text {theo }}=A \cdot C_{c} \cdot \frac{P}{\sqrt{R \cdot T}} \\
& C_{c}=\sqrt{\varkappa \cdot\left(\frac{2}{\chi+1}\right)^{\frac{\kappa+1}{\kappa-1}}}
\end{aligned}
$$

ここで，Q Q actual, $Q_{\text {theo }}, A, \chi, P, T$ ，および，Rは，そ れぞれ，ノズルの真の流量 $(\mathrm{kg} / \mathrm{s})$, 理想気体の一次元等工 ントロピー流れを仮定した理論流量 $(\mathrm{kg} / \mathrm{s})$ ，スロート面積 $\left(\mathrm{m}^{2}\right)$ ，よどみ点における比熱比，よどみ点圧力 $(\mathrm{Pa})$ ，よど み点温度 $(\mathrm{K})$, および, 気体に固有の気体定数 $(\mathrm{J} / \mathrm{K} \cdot \mathrm{kg}) て$ ある. $\mathrm{N}$ タイプノズルの流出係数は，定積槽システムに よって校正した結果によれば,

$$
C_{d}=0.9986-\frac{3.45}{\sqrt{R e}}
$$

にしたがう ${ }^{10)}$ こここで，Re は，スロート直径およびよどみ 点粘度に基づくレイノルズ数である.

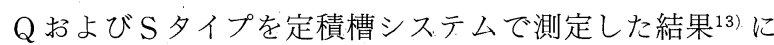
よれば, $\mathrm{Q}$ タイプは $\mathrm{N}$ タイプに比べて約 $0.1 \%$ 大きい流出 係数を持つが，Sタイプは $\mathrm{N}$ タイプと全く同じ流出係数を

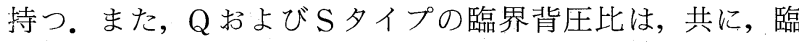
界圧力比に浪等しい約 0.5 となる．後付ディフューザは, これらの流出係数の值をほとんど変えることなく臨界範囲を 広げ，その臨界背圧比を N タイプとほとんど同じにまで改 善させる。

定積槽システムは，広い圧力比範囲における流量を積算 し，その間の平均流量を測定するため，流量の圧力比依存性 を詳細に調べることができない。個々の圧力比における流量 を詳細に調べるためには，次節に述べる直列接続校正法を用 いた.

\section{3. 流出係数の圧力比依存性の測定法およびその結果}

流出係数の圧力比依存性の測定は，Fig. 2 に示すように, 大気圧状態にある別の臨界ノズルを基準とし，その下流側に 測定対象ノズルを直列に接続して行なった ${ }^{15)}$. すなわち，測 


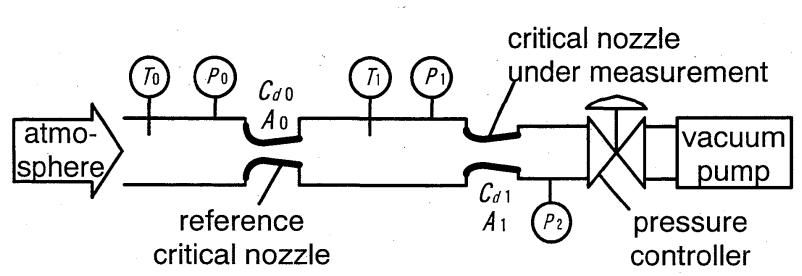

Fig. 2 Measurement of the discharge coefficient of the downstream critical nozzle against the upstream one kept at the atmospheric condition. The pressure ratio of the downstream nozzle is controlled by the pressure controller. A type $\mathrm{N}$ nozzle with $\mathrm{D}=6.7 \mathrm{~mm}$ was employed as the upstream nozzle. The nozzle under measurement was always kept at about $25 \mathrm{kPa}$, thus at the Reynolds number of $4.4 \times 10^{4}$.

定対象ノズルの下流にある圧力調整バルブで測定対象ノズル の圧力比を設定し, そのときの真の流量を, 上流側の基準ノ ズルから求めた．基準とする上流側ノズルには，スロート直 径 $6.7 \mathrm{~mm}\left(25 \mathrm{~m}^{3} / \mathrm{h}\right)$ の $\mathrm{N}$ タイプを用いた。このとき, 測定 対象ノズルの上流側圧力はノズルのスロート直径比でほぼ決 まり, 約 $25 \mathrm{kPa}$ の一定圧に保たれる.したがって, 上流側 ノズルは常に約 0.25 の圧力比に保たれ，十分に臨界する.

Fig. 2 において流れが定常であれば，それぞれのノズルの 質量流量は互いに等しくなる。したがって，下流側ノズルの 質量流量は, 上流側ノズルの圧力温度の測定值 $P_{0}, T_{0}$ お び(1)〜 (4) 式を用いて求めた上流側ノズルの質量流量とし て求めることができる.一方，下流側ノズルの理論質量流量 は, 下流側ノズルの上流側圧力温度の測定值 $P_{1}, T_{1}$ を用い て(2)式から求めることができる.したがって, 下流側ノズ ルの流出係数は, 上流側ノズルから求めた真の質量流量をこ れで割ることにより求めることができる.

すなわち, 下流側ノズルの流出係数 $C_{d 1}$ は, 上流側ノズ ルの流出係数 $C_{d 0}$ を用いて次式で与えられる。

$$
C_{d 1}=\frac{C_{d 0} \cdot A_{0} \cdot C_{c} \cdot \frac{P_{0}}{\sqrt{R \cdot T_{0}}}}{A_{1} \cdot C_{c} \cdot \frac{P_{1}}{\sqrt{R \cdot T_{1}}}}=C_{d 0} \cdot \frac{A_{0}}{A_{1}} \cdot \frac{P_{0}}{P_{1}} \cdot \sqrt{\frac{T_{1}}{T_{0}}}
$$

ここで， $A_{0}$ おょび $A_{1}$ は，それぞれ，上流側おょび下流側 ノズルのズロート面積 $\left(\mathrm{m}^{2}\right)$ である。 $C_{d 1}$ の変化は, (1) 〜 ( 2 ) 式からわかるように，そのまま臨界流量の変化を表わ す.

測定に用いた管路の詳細は文献 15 に示される。両ノズル の上流側には，ISO 9300 に準拠する整流管が取り付けられ ている.

Fig. 3 は, Q夕イプ, Sタイプ, N タイプ, および, Q夕 イプに後付ディフューザを取り付けたものの流出係数の圧力 比依存性を測定した結果である. 縦軸は, 圧力比 0.30 にお ける $\mathrm{N}$ タイプの流出係数を基準とし，これに対する各ノズ ルの流出係数の偏差を\%で表わす.

$\mathrm{Q}$ タイプおよび $\mathrm{S}$ タイプでは, 圧力比が約 0.5 を超える と亜音速流れとなり流量が急激に減少する. 長さ $0.1 \mathrm{D}$ の ディフューザを持つ S タイプの流出係数は, 臨界状態では,

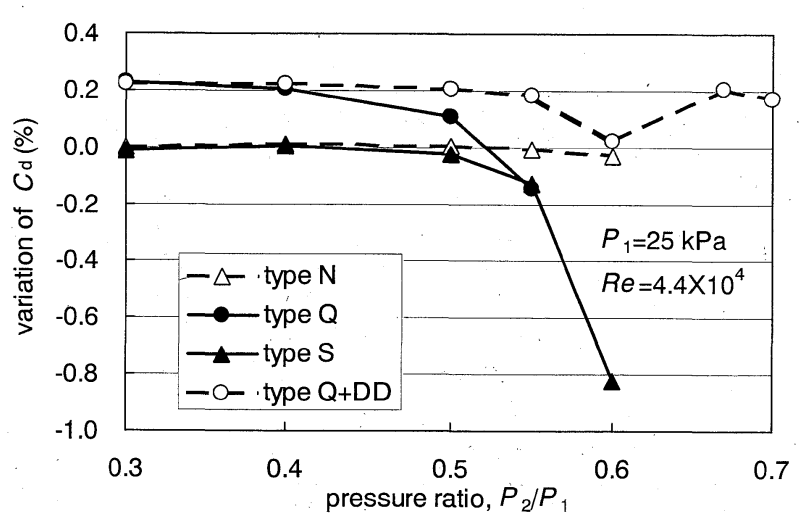

Fig. 3 The dependences of the discharge coefficients of the nozzles on the pressure ratio measured in the setup shown in Fig. 2. "type Q+DD" denotes the type Q nozzle attached by the detachable diffuser (DD).

一体型である $\mathrm{N}$ タイプとほとんど同じ值を持つ.これに対 し，正確にスロートで切り取られた Q夕イプの流出係数は， 圧力比 0.3 で $\mathrm{N}$ タイプより $0.2 \%$ 大きく, 圧力比の上昇と 共にこれが滅少し， 0.5 より若干大きい圧力比で $\mathrm{N}$ タイプ と同じ値となる。これ以上の圧力比では非臨界となり，S夕 イプと同様に急激に流量が減少する。定積槽システムによる $\mathrm{Q}$ タイプの校正では, N タイプより約 $0.1 \%$ 大きい流出係数 を持つという結果が得られていたが，これは，定積槽システ ムが $0.2 \%$ から $0.0 \%$ まで変化する流出係数を平均して測定 していたためと考えられる.

$\mathrm{Q}$ タイプに後付ディフューザを取り付けると, 臨界状態で は, 圧力比 0.3 における $\mathrm{Q}$ タイプ単体の流出係数の值が全 域で保たれる. 圧力比 0.6 において非臨界現象が観測されて いるが, 一体型 N タイプでも, 同じ圧力比で非臨界現象の 傾向が認められる. 後付ディフューザを S タイプに取り付 けた場合も, Qタイプでの場合と同様に, ディフューザ無し のときの流出係数がそのまま高圧力比まで保たれ, その特性 が N タイプとほぼ同じになることが確認されている。

\section{4. 回復温度分布に基づいた流速分布の測定法}

空気が流れる管路に細線熱電対線を挿入し，これを管路に 固定すると, 熱電対線の回りに境界層が発生し, 熱電対線の 接点位置における流れの回復温度 $T_{r}(\mathrm{~K})$ を測定することが できる，回復温度のよどみ点からの降下 $\Delta T_{r 0}(\mathrm{~K})$ は,

$$
\Delta T_{r 0} \equiv T_{r}-T_{0}=-(1-\sqrt{P r}) \cdot \frac{\varkappa-1}{2 \cdot R \cdot \varkappa} \cdot|\mathbf{V}|^{2}
$$

で与えられ, よどみ点温度 $T_{0}(\mathrm{~K})$ が一定であれば流速 $|\mathbf{V}|$ の自乗に比例する。したがって, 空気が流れる音速ノズル内 に熱電対線を張り, これをトラバースして管路内の回復温度 降下分布を測定すると，管路内の流速分布が得られる ${ }^{14)}$.

回復温度降下分布の図は, これに定数をかけて平方根をと り, 流速に変換するまでもなく, そのままで流速分布の様相 を表わしている。すなわち, 低い回復温度(または小さな $\left.\Delta T_{r 0}\right)$ は一意に速い流速を表わし, また, その逆も同様であ 


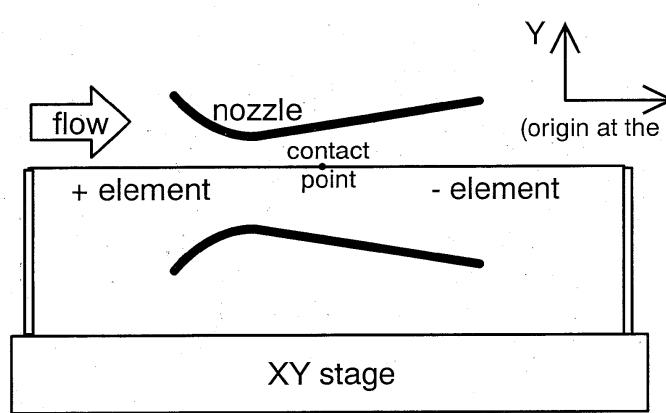

Fig. 4 A thermocouple wire settled in a nozzle to measure the recovery temperature of the flow exactly at the contact point. The location of the contact point is controlled by an XY stage.

る.このため, 以下では, 回復温度降下分布の図を基に流速 分布に関する議論を行なう。

測定に用いた熱電対線のトラバース装置は, 文献 14 に詳 細に示される。その概略はつぎのとおりである。すなわち， Fig. 4 に示すように，熱電対線をノズル軸と平行に張り，そ の接点位置をXY Xテージでノズル軸方向および直径方向 にトラバースする.このトラバース機構を持つチャンバは, Fig. 2 にある測定対象ノズルの位置に設置される。したがっ て，測定対象ノズルは，前節で述べた直列接続校正のときと 同じ状態に保たれる. 用いた熱電対線は, 線径 $50 \mu \mathrm{m}$ の K タイプである.ノズルの上流側に位置するチャンバー前室の 寸法は, 高さ $120 \mathrm{~mm}$, 幅 $170 \mathrm{~mm}$, 上流側への長さ 170 mmであり, ISO 9300 に規定される「大空間」にほぼ適合 し，十分安定した流れがノズルに供給される。

\section{5. 回復温度分布測定の不確かさ}

トラバースに取り付けた熱電対線の校正は事実上不可能で あるため，以下の測定では熱電対線を校正せずに用いた。

熱電対には個体差により測定温度の絶対値にかなりのばら つきがある. 本測定では，その影響を抑えるため，ノズルの 入り口面(スロートより約 $21 \mathrm{~mm}$ 上流)で半径方向にトラ バースして測定した温度の平均值をよどみ点温度とみなし, $\Delta T_{r 0}$ を求めた。 スロート直径の 2.5 倍の直径を持つ入り口 面には平均して約 $32 \mathrm{~m} / \mathrm{s}$ の流速が発生しているが, その回 復温度はよどみ点温度より $0.1 \mathrm{~K}$ 弱低いだけであり，これ による測定誤差は無視し得る。

熱電対線の感度にも個体差によるばらつきがあるが, 測定 範囲である常温の $20 \mathrm{~K}$ 程度の範囲では, 感度差による測定

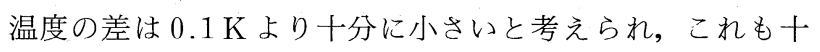
分無視し得る。

最も大きな誤差要因の一つは, 測定に数時間を要するた め, その間の環境温度, すなわち, よ゙とみ点温度の変化と考 えられる.よどみ点温度の変化は, プラントル数が 1 に近い ため, ほとんどそのまま回復温度の変化として現われる。測 定室の室温変化は, 通常, 数時間の間で $0.2 \mathrm{~K}$ 程度に抑え られているため, これによる回復温度の不確かさは, \pm 0.2 $\mathrm{K}$ 程度とみなせる。よどみ点温度からの降下 $\Delta T_{r 0}$ を用いる

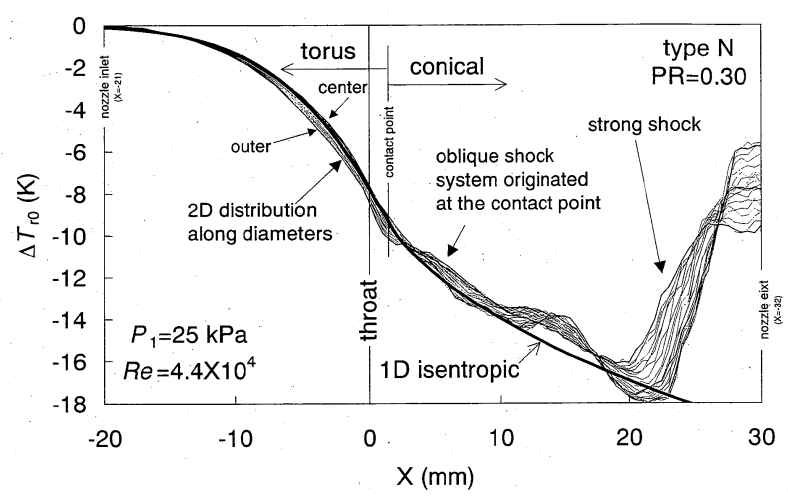

Fig. 5 An example of the measured recovery temperature distributions in a type $\mathrm{N}$ nozzle kept at the pressure ratio of 0.30 . Multiple measurements along lines parrallel to the $\mathrm{X}$ axis at various $\mathrm{Y}$ are superimposed. 'center' and 'outer' denote the distributions measured along the axis of the symmetry and on the most outside line attaching the throat wall, respectively. The thickest line was calculated from the well-known $1 \mathrm{D}$ isentropic theory together with the recovery factor of $\sqrt{P r}$ where $P r$ is the Prandtl number. The contact point of the torus and conical portions causes an oblique shock system. The large jump near the nozzle end is a strong shock.

場合は, 測定室の平均温度の差の影響は無視できる.

最後に, 十分検討されていないためにその影響が未知であ る不確かさ要因として, 熱電対線の取り付け方の差がある. 非常に細い熱電対線をトラバースに取り付けるのは非常に難 しく, 張られた線とノズル対称軸との平行度, 張力(すなわ ち測定中の線のぶれ)，測定線の形状，等にはある程度のば らつきがある。これらの熱電対線の状態がもたらす不確かさ を解析するためには，さらなる実験，検討，または，高度な サポートを持つトラバース機構が必要であるが, これまでの 予備実験では，測定される回復温度は流れの入射角度に依存 せず，熱電対線は，（6)式にあると抢り，接点位置における 流速の絶対值を測定すると考えられる。したがって，張られ た線の傾きによる測定誤差は無いと考えられる。また，線の ぶれは，ぶれ幅での平均温度を示すと考えられ，その影響は 大きくないと考えられる。これまで，ぶれや傾きの差によっ て測定結果に大きな差が認められたことは無い.

以上により，以下に示される $\Delta T_{r 0}$ の不確かさは，全体と して $\pm 0.2 \mathrm{~K}$ を超えない程度と評価される. $0.2 \mathrm{~K}$ の温度不 確かさは，スロートにおいて流速の $4 \mathrm{~m} / \mathrm{s}$ の不確かさに相 当し，たとえば，これより流速が大きいとその不確かさは小 さくなる。一方，スロートに打る直径方向の回復温度分布 を議論する際には，測定に要する時間が数分であるため不確 かさ要因がほぼ熱電対線の感度だけとなり, かつ, 分布がせ いぜい $3 \mathrm{~K}$ 程度の範囲内にあるため, 不確かさは $0.1 \mathrm{~K} よ$ りも十分に小さいと考えられる。測定温度の標準偏差は，大 きい場合でも $0.1 \mathrm{~K}$ 以下である。

Fig.5 は， N タイプノズルについてX 軸方向に測定した 回復温度分布である. 複数の線が重なっている理由は, 半径 
方向に異なる位置での測定を重ねたためである，図中の centerはノズルの対称軸上での測定值を表わし， outer は最 も外側での測定值を表わす。熱電対線はノズルの対称軸と平 行に張られているため, outerでの測定を行なう際には，接 点は，スロート壁面にほぼ接した直線上を通る ${ }^{14)}$.

回復温度の測定值は，一次元等エントロピー流れを仮定し た理論值 (太線) と非常によく一致する．ただし，強い衝撃波 を含め，単純な理論では予測不可能なさまざまな流れの構 造，すなわち，円環部と円錐部の接点から発生した斜め衝撃 波などが検出されており ${ }^{14)}$ ，これらの位置では理論值と大き く異なる。この円環部と円錐部の接点より前では，回復温度 の測定値と理論值は非常によく一致する。この範囲で outer での温度が center より若干低い理由は，後に述べるように， 主流の二次元性が検出されているためである，以上により， 上に評価した $\pm 0.2 \mathrm{~K}$ を越えない不確かさというのは十分理 にかなった大きさと考えられる。

\section{6. 回復温度分布の測定結果}

Fig. 6a） d) は，各ノズルをさまざまな圧力比に保ち，ス ロート位置で半径方向に測定した回復温度降下分布である。 大きな温度降下は流速が大きいことを示す。臨界流量は，こ の分布から求めた流速をスロートにわたつて積分したものと なる。図中右側の縦線はノズルの対称軸，左端はスロート壁 面に対応する，図中の PR は圧力比を表わす。

Fig. 6 a) は, 一般的形状を持つ N タイプノズルの分布で ある．壁面近傍で回復温度が低くなっている理由は，主流分

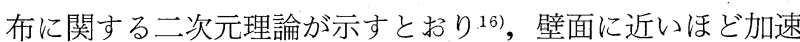

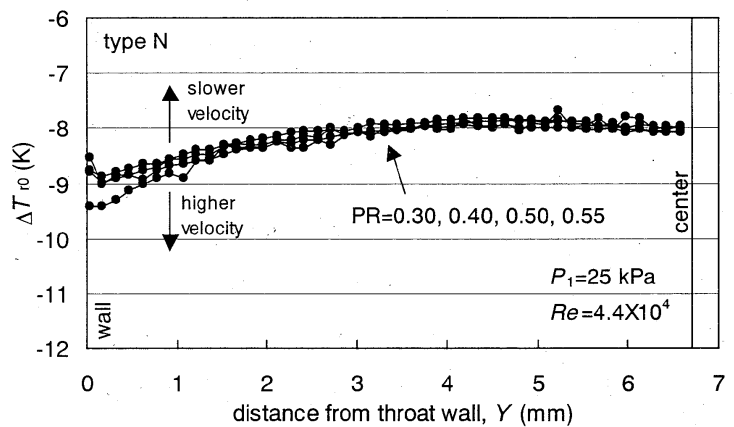

a) Type $\mathrm{N}$

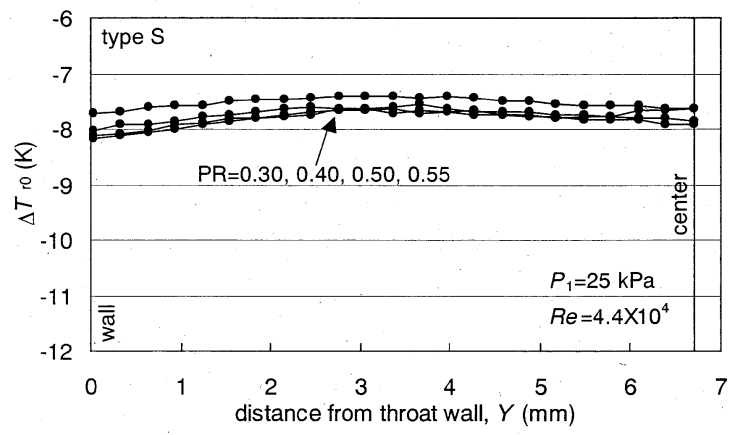

c) Type $\mathrm{S}$
の原因となる壁面曲率の影響を大きく受け，大きく加速され るためである。これらの分布は圧力比に依存せず一定で，す なわち，その臨界流量が圧力比に依存せず一定であることを 表わしている。

Fig. 6 b) は，スロートで切り取られた四分円ノズル Q 夕 イプの分布である. 中心部分では圧力比にかかわらず N タ イプとほぼ同じ形の分布を持つが，圧力比が低いほど壁面近 傍の回復温度が大きく下がっている。これは，圧力比が低い ほど壁面近傍が異常に加速されていることを表わし，すなわ ち，その臨界流量が，低い圧力比では $\mathrm{N}$ タイプより大きく， 圧力比の上昇と共にこれが減少することを説明する。

Fig. 6 c) は，スロート後方に $0.1 \mathrm{D}$ という非常に短いディ フューザを持つ S タイプの分布である．Nタイプと同様に 平らな分布を持ち，また，圧力比に依存しない.このこと は，このノズルの臨界流量が，Nタイプとほぼ同じでその 圧力依存性が無いことを説明する。

Fig. 6 d) は，四分円ノズル Q タイプに後付ディフューザ $\mathrm{DD}$ を取り付けたときの分布である。その形は $\mathrm{Q}$ タイプ単体 の圧力比 0.30 のときとほぼ同じであるが，圧力比依存性が 無い.すなわち, 臨界流量が $\mathrm{Q}$ タイプの圧力比 0.30 での流 量と同じで，その值が圧力比に依存せず一定に保たれること を説明する。

Fig. $7 \mathrm{a}) \sim_{\mathrm{C}}$ は，各ノズルについて，庄力比を 0.30 また は 0.50 とし，さまざまな $\mathrm{Y} に ゙ お け る \mathrm{X}$ 軸方向の回復温度 降下分布を測定した結果である. 先に示した Fig. 6 の分布 は，Fig. 7 でのスロート位置 $\mathrm{X}=0$ における分布を $\mathrm{Y}$ 方向に 示したものとなる.したがって, Fig. 7 では, Fig. 6 で知ら

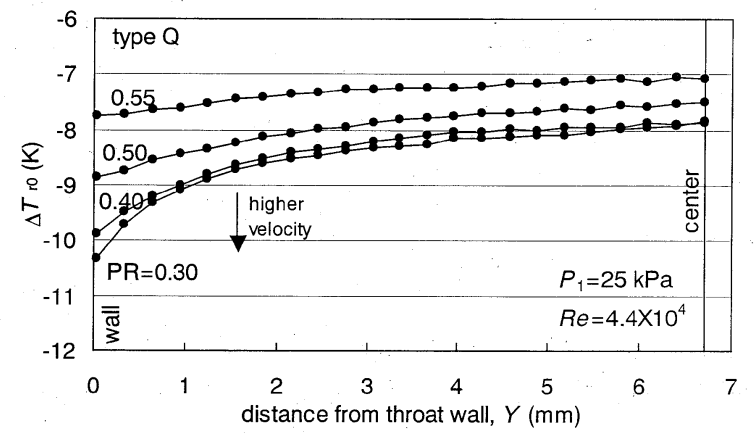

b) Type $\mathrm{Q}$

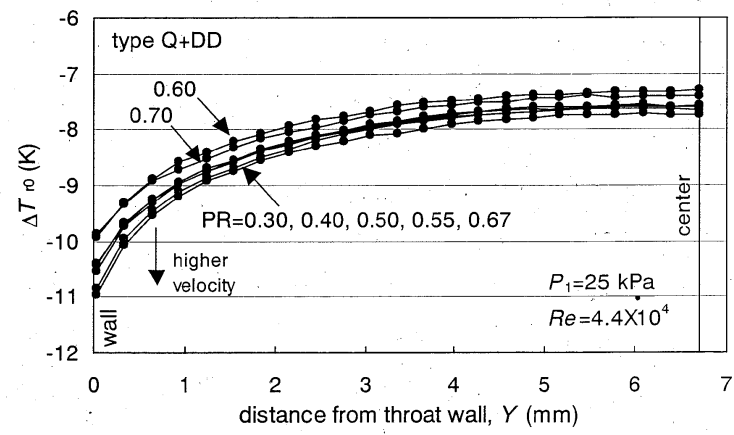

d) Type Q with the detachable diffuser (DD)

Fig. 6 Recovery temperature distributions measured along a radius on the throat of the type N(a), type Q (b), type $S$ (c), or type Q nozzle with the detachable diffuser(d). Multiple measurements at several pressure ratios(PR) are superimposed. 

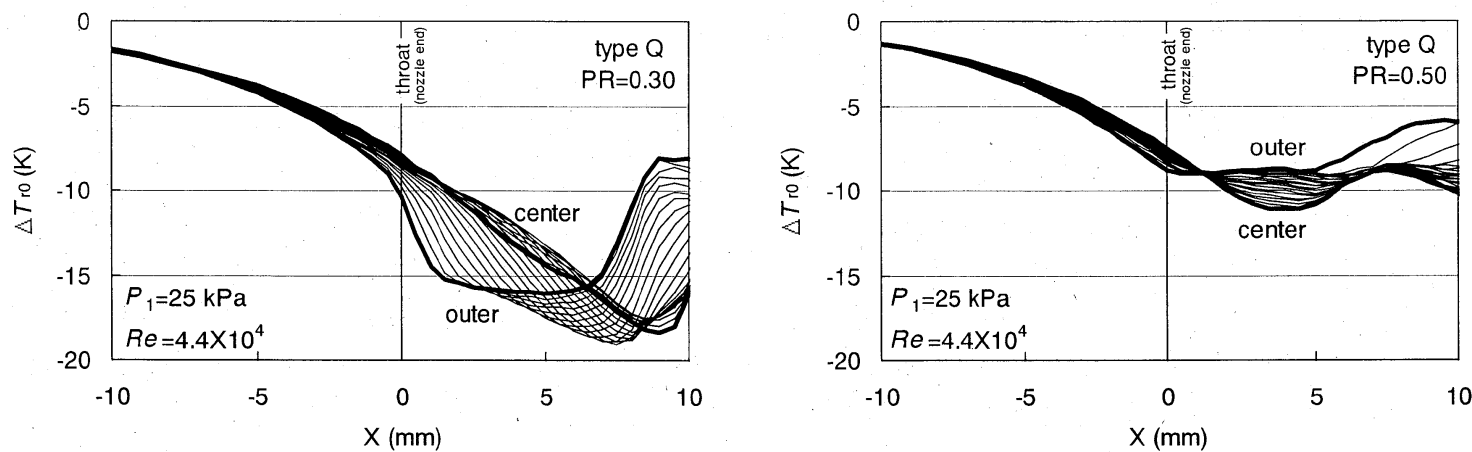

a) Type Q
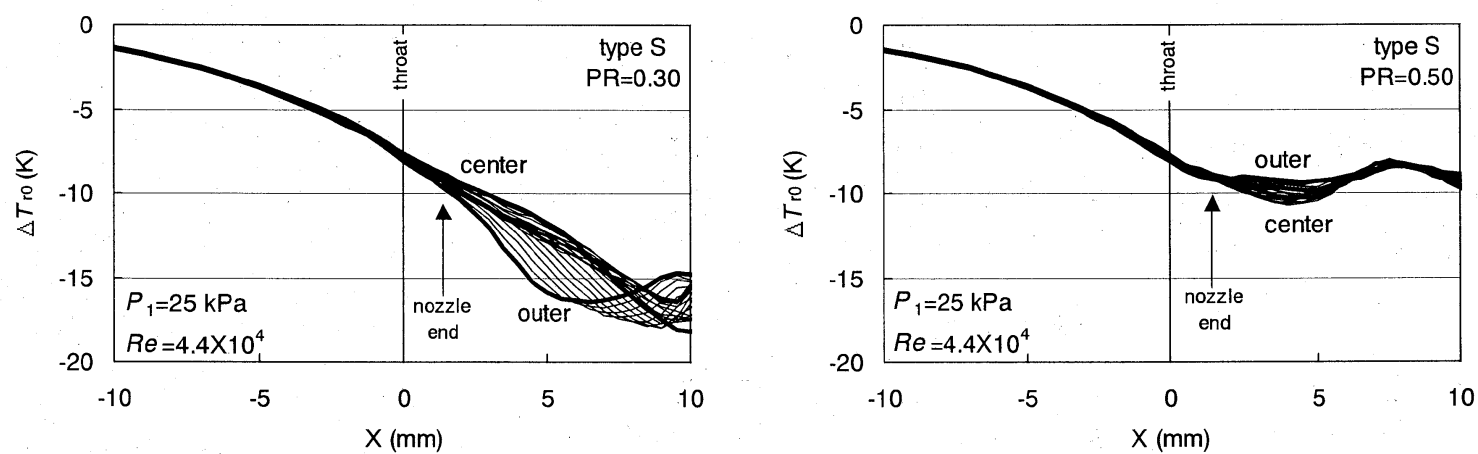

b) Type $\mathrm{S}$
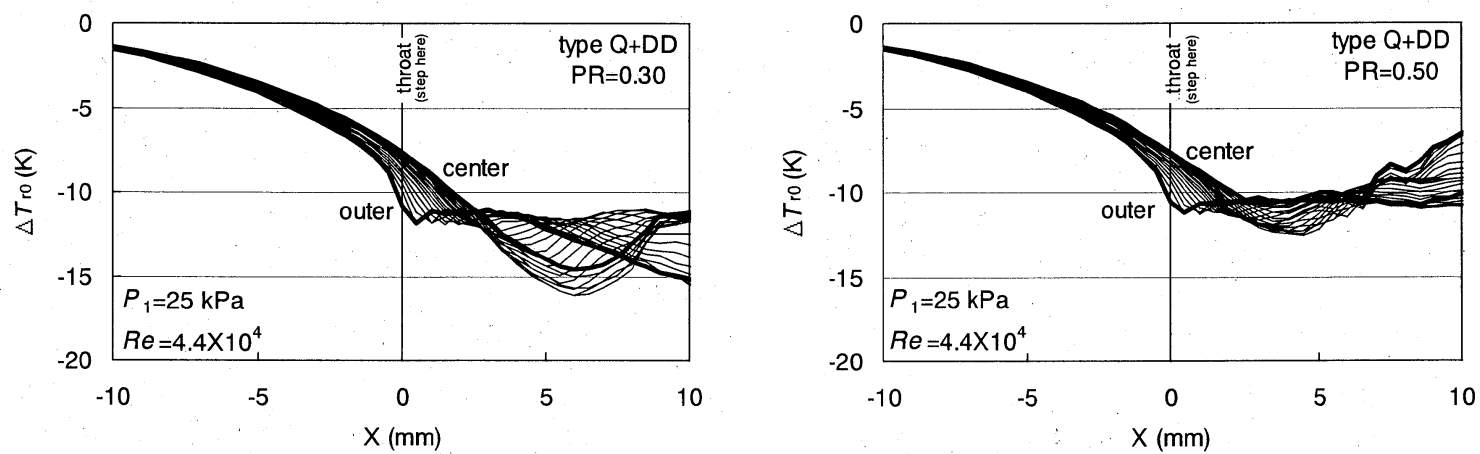

c) Type $Q$ with the detachable diffuser (DD)

Fig. 7 Recovery temperature distributions measured along lines parallel to the $\mathrm{X}$ axis in the type $\mathrm{Q}(\mathrm{a})$, type $\mathrm{S}$ (b), or type $\mathrm{Q}$ nozzle with the detachable diffuser (c).

れた現象が，スロート前後でどのように変化するかを知るこ とができる，図中の center および outer は，それぞれ，測 定線がノズル対称軸上およびこれに平行でほぼスロートに接 する線上にあることを示す。

Fig. 7 a) は, Q夕イプの分布である. 圧力比 0.3 のとき, outer 側がスロート後方で大きく下がっている.これが Fig. 6 b)で見られた壁面近傍の急激な加速である．加速の原因と なるエッジは超音速流れが始まるスロートにあるが，これよ り上流が亚音速であるため，この加速の影響が上流側の広い 範囲に及んでいる．この加速は，圧力比 0.5 で消え失せる.

Fig. 7 b) は，Sタイプの分布である.Qタイプと同様な エッジによる加速が見られるが，これが超音速流れ内で始ま るため，その影響が下流側にのみ流れ，スロート面には影響 を及ぼしていない。それ以外は，Q夕イプとほぼ同じ振る舞 いを示す。
Fig. 7 c) は，Qタイプに後付ディフューザを取り付けたと きの分布である．流れが後付ディフューザの壁面に当たるま では, 圧力比 0.30 における $\mathrm{Q}$ タイプの分布と同じになって いる.しかし，流れがディフューザ壁面に達すると，エッジ による加速が急激に止められる。この急激な加速の停止は超 音速領域で発生し，これにより下流側状態の情報が遮断さ れ，スロートにおける分布が圧力比に依存しなくなる。

Fig. 8a)〜C) は，さまざまな圧力比における各ノズルの回 復温度降下分布を，三次元的に示したものである， Y 軸に ある“o”および“c”は，それぞれ，最も外側の線に沿った 測定 (outer)，および，ノズルの対称軸に沿った測定 (center）を指す：これまでの図と同様に，大きな温度降下は流速 が大きいことを表わす。これらの図には非常に多くの流れ構 造に関する情報が含まれており，その詳細を述べることは本 論文の範囲を超えるものであるが，たとえば，つぎのよう 


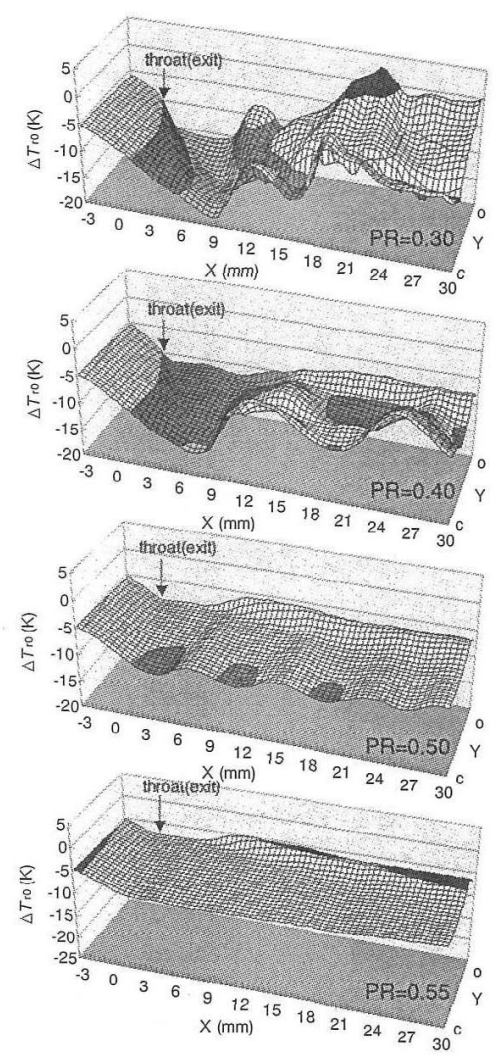

a) type Q

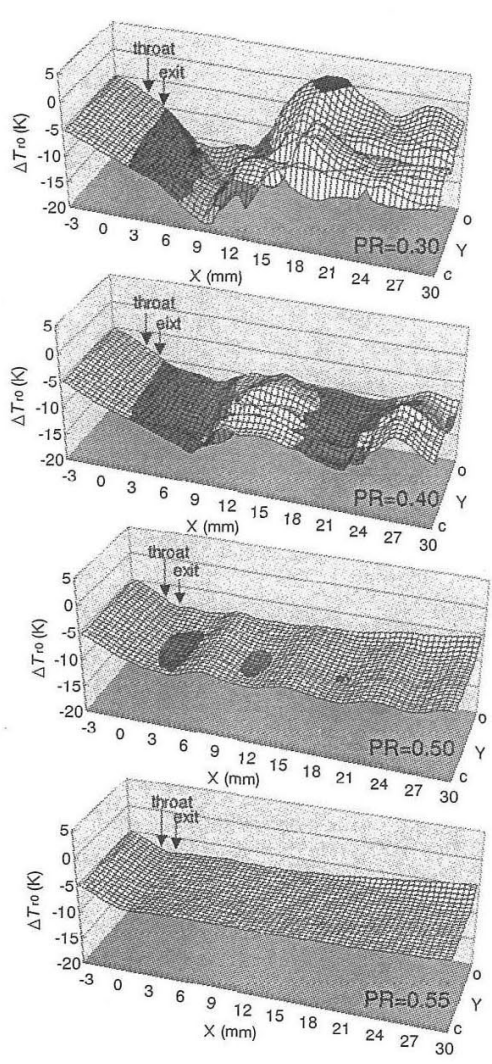

b) type $\mathrm{S}$

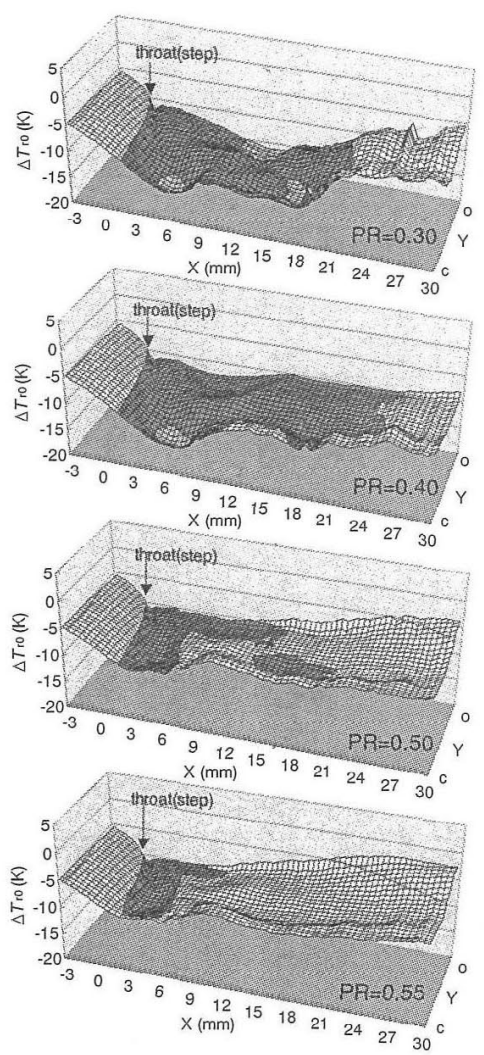

c) Type Q+DD

Fig. 83 D plots of the recovery temperature distributions measured in the type $\mathrm{Q}(\mathrm{a})$, type $\mathrm{S}(\mathrm{b})$, or type $\mathrm{Q}$ nozzle with the detachable diffuser (c).

に，Fig. 6 おうよび Fig. 7 で知られた現象が，下流側に向かっ てY方向にどのように変化するかが見て取れる。

$\mathrm{Q}$ タイプ(Fig. 8 a)では, 圧力比 0.300 とき, スロートに あるエッジによる加速(急激な温度降下)がスロート近傍から 発生し，中心に向かって斜めに伝播する。これが中心軸に到 達するとそそこから大きな流れの構造が発生する。この伝播 する加速は，圧力比が大きくなると，方向は変わらないが大 きさが小さくなる．圧力比 0.50 になると，流れに沿って規 則正しい加減速構造が発生する。圧力比 0.55 では，スロー 卜後方の流れは一様となり，吕染音速に近い一定流速を保っ た噴流となる。Sタイプ(Fig. 8 b) の振る舞いもほぼ同じで ある。Qタイプに後付ディフューザを取り付けた場合 (Fig. 8c) は，エッジによる加速と壁面によるその停止が Q夕イプ 単体の場合と同様に斜めに伝播する。この急激な加速と停止 の様子は，圧力比が変わって下流側分布が変わっても同じに 保たれる。

\section{7. まと め}

過去に行なわれた定積槽システムによる校正によると, 一 般的な形状を持つディフューザ一体型のトロイダルスロート ベンチュリノズル (以下， $N$ ノズルと略する)，これを正確 にスロート位置で切断した四分円ノズル(以下，Qノズルと
略する)，Qノズルと非常によく似た形状を持つが，スロー ト後方に長さ $0.1 \mathrm{D}$ ( D はスロート直径) の非常に短いディ フューザを持つノズル(以下，Sノズルと略する)，および， Q または S ノズルに後付ディフューザを取り付け接続面に 0.01 Dの微小なステップを持たせた臨界ノズルの中には， 互いに非常に似た形状を持つにもかかわらず流量に大きな差 が見られる場合がある。本論文では，これらのノズルの臨界 流量の圧力比依存性を直列接続校正法により測定し, また, その結果が，回復温度分布の測定值から推定した流速分布に より明解に説明できることを示した。回復温度降下以流速の 自乗に比例するため，その分布は，そのままでも流速分布の 様相を表わしている。回復温度分布には，流量測定等では全 く知ることのできない多くの流れ構造に関する詳細情報が含 まれ，遷音速流机場の解析に非常に有用であることを示し た。

臨界ノズルの直列接続試験では，つぎのことがわかった。 すなわち，Qノズルでは，低い圧力比で $\mathrm{N}$ ノズルに対して $0.2 \%$ 大きな流量となり，圧力比を上げるとその流量が減少 し, 圧力比 0.5 で $\mathrm{N}$ ノズルとほぼ同じ流量となる。一方, $\mathrm{S}$ ノズルでは, 臨界状態ではNノズルと全く同じ流量を持ち, その厈力此依存性も無い. Q ノズルに後付ディフューザを取 り付けると, その臨界流量は圧力比に依存しなくなり, 低圧 
力比における $\mathrm{Q}$ ノズルの大きな臨界流量と同じ值が保たれ る.

線径 $50 \mu \mathrm{m}$ の熱電対線を用いた回復温度分布測定では, つぎのことが明らかとなり, 直列接続校正による結果を明解 に説明できた。すなわち，Qノズルのスロート位置での半径 方向の分布測定では, 壁面近傍で大きな加速が検出され, ま た，その加速の大きさが圧力比を上げると小さくなり，圧力 比 0.5 でNノズルの分布と似た分布となる。 S ノズルでは, スロート全体にわたって平坦な分布となり，かつ圧力比依存 性が無い。エッジによる加速は超音速流れの中で始まり，そ の影響は下流側に流れてスロートに影響を及ぼさない.Q， ズルに後付ディフューザを取り付けると，超音速流れ内で流 れがディフューザ壁面に当たってエッジによる加速が急激に 止められ，これにより下流側情報が遮断されてスロートでの 分布が固定され，臨界流量の圧力比依存性が無くなる。この ほか，エッジや段差によって発生した斜め衝撃波がディ フューザ内の超音速流れ場の構造を形成していく様子，およ び，圧力比によってその構造が変化していく様子が明白に捉 えられた。

\section{参 考 文 献}

1) B. T. Arnberg, C. L. Britton and W. F. Seidl: Discharge Coefficient Correlations for Circular-Arc Venturi Flowmeters at Critical Flow, ASME Paper No. 73-WA/FM-8 (1974)

2) W.F. Seidl : Primary calibration of the Boeing $18 \mathrm{~kg} / \mathrm{sec}$ airflow calibration transfer standard, Proceedings of international symposium on fluid flow measurement, 97/107 (1986)

3) Brain and MacDonald: Evaluation of the performance of small-scale critical flow venturi using the NEL gravimetric gas flow standard test facility, Fluid Flow Measurement in the Mid 1970s, 103/125 (1977, Edinburgh)

4) S. Nakao et al. : A study on the conversion factor of sonic Venturi nozzles, Proc. of NCSL International Workshop \& Symposium (July 2001, Washington DC)

5) Bignell : Comparison techniques for small sonic nozzles, Flow Meas. Instrum. 7-2, 109/114 (1996)

6) Caron, Britton and Kegel: Investigation into the premature unchoking phenomena of critical flow venturis,
Proceedings of ASME FEDSM 2000-11108 (June 2000, Boston)

7) von Lavante, Ishibashi and Wendt: Investigation of Flowfields in Small Sonic Venturi-nozzles, Proceedings of FLOMEKO 00 (June 2000, Brazil)

8) ISO/CD 9300, Measurement of gas flow by means of critical flow Venturi nozzles (2003)

9) Karnik, Bowles, Bosio and Caldwell: North American Inter-Laboratory Flow Measuremet Testing Program, North Sea Flow Measurement Workshop, Paper No.3 (1996, Scotland)

10) Ishibashi and Takamoto: Theoretical discharge coefficient of a critical circular-arc nozzle with laminar boundary layer and its verification by measurements using super-acurate nozzles, Flow Measurement and Instrumentation 11-4, 305/314 (2000)

11）石橋, 高本：超精密加工音速ノズルの加圧試験, 計測自動制御 学会論文集, 36-1, 1/9 (2000)

12）石橋, 大梘：超精密加工臨界ノズルに発生する境界層遷移の 精密測定, 計測自動制御学会論文集, 38-4, 351/360 (2002)

13) Ishibashi and Takamoto: Discharge Coefficient of Critical Nozzles Machined by Super-Accurate Lathes, Proceedings of the 1998 NCSL Workshop and Symposium, 423/442 (July 1998, Albuquerque)

14）石橋, 高本：細線熱電対を用いた回復温度測定に基づく準非 侵襲な軸対称音速ノズル内遷音速流速分布の測定, 37-7, 計測 自動制御学会論文集, 609/617 (2001)

15）石橋, 高本, 中尾, 横溝：音速ノズルの直列接続による試験と その応用, 計測自動制御学会論文集, 34-7, 698/706(1998)

16) I. M. Hall: Transonic Flow in Two-dimensional and Axially-symmetric Nozzles. Quart. Journ. Mech. and Applied Math., XV-4, 487/508 (1962)

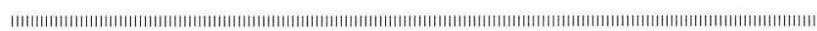

$$
\text { [著 者紹介] }
$$

石 橋 雅 裕 (正会員)

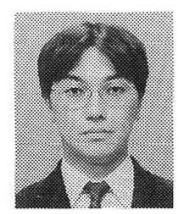

1985 年, 筑波大学大学院博士課程物理工学専 攻修了。同年，工業技術院計量研究所(現産業技 術総合研究所) 入所, 現在に至る。気体流量標準, 臨界ノズルの研究に従事(工学博士)。

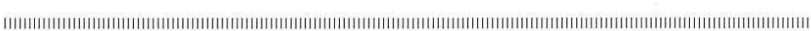

